\title{
Distribution of Metals in Organs and Tissues of Cyprinus carpio L., 1758 from Kizılırmak
}

\author{
Öztekin YARDIM* Levent BAT \\ University of Sinop, Fisheries Faculty, Department of Hydrobiology, 57000 Sinop, Turkey
}

How to cite: Yardım, Ö. \& Bat, L. (2020). Distribution of metals in organs and tissues of Cyprinus carpio L., 1758 from Kızllirmak. J. Anatolian Env. and Anim. Sciences, 5(3), 290-294.

Atıf yapmak için: Yardım, Ö. \& Bat, L. (2020). Kızılırmak'ta Yaşayan Cyprinus carpio L., 1758'nun Organ ve Dokulardaki Metallerin Dağılımı. Anadolu Çev. ve Hay. Dergisi, 5(3), 290-294.

*iD: https://orcid.org/0000-0002-7753-5922

(iD) : https://orcid.org/0000-0002-2289-6691

\section{*Corresponding author's:}

Öztekin YARDIM

University of Sinop, Fisheries Faculty,

Department of Hydrobiology, 57000 Sinop.

Turkey

$\triangle$ : oyardim@sinop.edu.tr

Mobile telephone: $+90(533) 5635485$

Telephone : $+90(368) 2876265$

Fax $\quad:+90(368) 2876268$

\begin{abstract}
The bioaccumulation of metals in the common carp Cyprinus carpio L., 1758 was monitored to assess the pollution status in Kiz1lirmak. The common carp samples were captured by local fishermen and were purchased from fish markets in Bafra. Liver, gill, stomach + intestine, skin and muscles of $C$. carpio were analyzed for $\mathrm{Fe}, \mathrm{Zn}, \mathrm{Cu}, \mathrm{Pb}, \mathrm{Hg}$ and $\mathrm{Cd}$ using an inductively coupled plasma mass spectrometry (ICP-MS). Metal concentrations in the common carp occurred in the order: $\mathrm{Fe}>\mathrm{Zn}>\mathrm{Cu}>\mathrm{Pb}>\mathrm{Hg}>\mathrm{Cd}$. The non-essential metals $\mathrm{Cd}, \mathrm{Hg}$ and $\mathrm{Pb}$ in edible tissues of common carp were below the detection of limits. The muscle tissues had also the lowest concentrations for essential metals. Higher concentrations of $\mathrm{Fe}, \mathrm{Zn}, \mathrm{Cu}$ and $\mathrm{Pb}$ in $C$. carpio were liver $>$ stomach + intestine $>$ gill $>$ skin $>$ muscle, while the $\mathrm{Hg}$ and $\mathrm{Cd}$ levels were liver $>$ gill $>$ stomach + intestine $>$ skin $>$ muscle, respectively.
\end{abstract}

Keywords: Cyprinus carpio, metals, Kizılırmak, gill, liver, muscle, skin, stomach+intestine.

\section{Kızlırmak'ta Yaşayan Cyprinus carpio L., 1758'nun Organ ve Dokulardaki Metallerin Dağılımı}

\section{*Sorumlu yazar:}

Öztekin YARDIM

Sinop Üniversitesi, Su Ürünleri Fakültesi,

Hidrobiyoloji Bölümü, 57000 Sinop, Türkiye

$\bowtie$ : oyardim@sinop.edu.tr

Cep telefonu: +90 (533) 5635485

Telefon : $+90(368) 2876265$

Faks $\quad:+90(368) 2876268$
Öz: Kızılırmak'taki kirlilik durumunu değerlendirmek için sazan balıklarındaki (Cyprinus carpio L., 1758) metallerin biyoakümülasyonu izlenmiştir. Yerel balıkçılar tarafindan yakalanan sazan balığı örnekleri Bafra'daki balık pazarlarından satın alınmıştır. İndüktif Eşleşmiş Plazma Kütle Spektrometresi (ICP-MS) kullanılarak C. carpio türünün karaciğer, solungaç, mide + bağırsak, deri ve kasları $\mathrm{Fe}, \mathrm{Zn}, \mathrm{Cu}, \mathrm{Pb}, \mathrm{Hg}$ ve $\mathrm{Cd}$ için analiz edilmiştir. Sazan balıklarındaki metal konsantrasyonları sırasıyla $\mathrm{Fe}>\mathrm{Zn}>\mathrm{Cu}>\mathrm{Pb}>\mathrm{Hg}>\mathrm{Cd}$ olarak bulunmuştur. Sazanların yenilebilir dokularındaki esansiyel olmayan metaller $\mathrm{Cd}, \mathrm{Hg}$ ve $\mathrm{Pb}$ ölçüm sınırların altında tespit edilmiştir. Kas dokuları esansiyel metaller için de en düşük konsantrasyonlarda bulunmuştur. C. carpio türünde $\mathrm{Fe}, \mathrm{Zn}, \mathrm{Cu}$ ve $\mathrm{Pb}$ konsantrasyonları sırasıyla karaciğer $>$ mide + bağırsak > solungaç> deri $>$ kas olarak daha yüksek değerde iken, $\mathrm{Hg}$ ve $\mathrm{Cd}$ seviyeleri için karaciğer $>$ solungaç> mide + bağırsak $>$ deri $>$ kas şeklinde tespit edilmiştir.

Anahtar kelimeler: Cyprinus carpio, deri, karaciğer, kas, Kızılırmak, mide+bağırsak, metaller. 


\section{INTRODUCTION}

The Kizılirmak Delta where located in the central Black Sea region of Turkey $\left(41^{\circ} 30^{\prime}\right.$ to $41^{\circ} 45^{\prime} \mathrm{N}, 35^{\circ} 43^{\prime}$ to $36^{\circ} 08^{\prime}$ E), between the Samsun and Sinop highway within the borders Bafra, Alaçam and Ondozkuzmayıs townships of Samsun, is one of Turkey's most important wetland complexes with its rich biodiversity and critical habitat for globally endangered bird species (Özesmi, 2006). The Kizılırmak Delta is located in the central Black Sea region, is one of Turkey's most important wetland complexes and the only designated Ramsar site in the basin (Schelle et al., 2004). The Kizllırmak is the longest river entirely within Turkey. Kızılırmak ends in the Black Sea from the shores of Bafra which is a district in the Samsun Province of Turkey.

Major threats in the Kizılırmak Delta are drainage and irrigation projects, pollution and filling of lakes with agricultural chemicals, illegal urbanisation on the coastal zone, sand extraction and uncontrolled hunting, degradation of the coastline due to the absence of alluvial flows from lower courses of the river after dam construction. The wetland is polluted by agricultural runoff and untreated sewage from Bafra, leading to eutrophication (Akbulut et al., 2000). The Kizilırmak accumulates a significant amount of nutrients, metals and other compounds in its basin as a result of anthropogenic activities (Bakan et al., 2010). Kizılırmak is one of the most important river in the Black Sea Region, and many industries are located in this region and it has been reported that most of them do not have treatment plants and potentially cause local pollution problems (Altas and Büyükgüngör, 2007). The treated wastewater of Bafra town is discharged to Kizılırmak Delta (Samsunlu et al., 2002).

Metals eventually enter in food chains and their bioaccumulation and magnification can cause physiological and morphological alterations not only in aquatic animals but in human beings as well. In this sense, fish are very important because they are the preferred food in human consumption. C. carpio is a very popular type of fish because it is cheap. They are omnivorous, they can be cultured. The high growth rates also make them commercially preferable. They spend the winter periods at the bottom for protection from the cold. They can also live in low salt waters. They are found in muddy, abundant vegetation, turbid and heavily flowing waters. Growth biology, age determination of this species in the region were studied by many researchers (Demirkalp, 1992a, b; Y1lmaz and Polat, 2008; Y1lmaz et al., 2012). However, metal accumulation studies in carp are partially less (Öztürk et al., 1995; Bat et al., 2015; Bat and Öztekin, 2018). However, these studies should be done regularly and evaluated in terms of public health. Nowadays, attempt to determine metals in fish have drawn a major issue of interest. The main purpose of this study is to determine metal accumulation in different organs and tissues of the most common and delicious carp fish Cyprinus carpio L., 1758 .

\section{MATERIAL AND METHOD}

The common carp C. carpio in Kizılırmak were obtained from local fishermen at landing sites in Bafra. A total of ten specimens were purchased. Mean lengths ranged from $35 \mathrm{~cm}$ to $46 \mathrm{~cm}$ and mean weights of the samples ranged from $520 \mathrm{~g}$ to $2130 \mathrm{~g}$. The samples were washed with clean water and put in ice boxes and transported to laboratory. After measuring body weight and total length, fish samples were dissected in the laboratory where the liver, entire gill, stomach + intestine, skin and muscle tissues and organs were removed from each fish individuals and frozen for metals analysis according to Bernhard (1976).

All fish samples were wet digested and concentrations of $\mathrm{Cd}, \mathrm{Hg}, \mathrm{Pb}, \mathrm{Cu}, \mathrm{Zn}$ and $\mathrm{Fe}$ were determined using inductively coupled plasma mass spectrometry (ICP-MS) method by accredited Environment Industrial Analysis Laboratory Services Trade Company (TÜRKAK Test TS EN ISO IEC 17025 AB-0364-T). The method for determination of these metals, used acid, standard reference material, wet digestion was used by European standard method with number EN 15763.

The data obtained from metals analysis was statistical analyzed by analysis of variance (ANOVA) and Tukey test to find out significant levels among fish tissues (Zar, 1984). SPSS software version 21.0 was used for statistical analysis. Differences were considered significant at $\mathrm{p} \leq 0.05$.

\section{RESULTS AND DISCUSSION}

Mean levels of metal concentrations $\left(\mathrm{mg} \mathrm{kg}^{-1} \pm\right.$ $\mathrm{SD}$ wet wt.) found in tissues of $C$. carpio are presented in Figures 1 and 2. The concentrations of the essential metals, $\mathrm{Fe}, \mathrm{Zn}$ and $\mathrm{Cu}$ were always higher than those of the nonessential metals $\mathrm{Pb}, \mathrm{Hg}$ and $\mathrm{Cd}$. Tukey HSD multiple comparisons post-hoc test was used to determine whether there was a statistically significant difference between tissues or not. There were statistically significant differences between organs and tissues of the common carp $(p<0.05)$. The results of the current study showed that the metal levels in liver tissues, gill, stomach + intestine and skin were higher than those in the muscle tissues. The results show that all the non-essential metals $\mathrm{Cd}, \mathrm{Hg}$ and 
$\mathrm{Pb}$ in edible tissues of the common carp were below the detection of limits. Detection of limits for $\mathrm{Cd}, \mathrm{Hg}$ and $\mathrm{Pb}$ were $0.002,0.001$ and $0.005 \mathrm{mg} / \mathrm{kg}$, respectively (Figure 1). European Commission regulation (EC, 2006) indicates that maximum levels of $\mathrm{Pb}, \mathrm{Hg}$ and $\mathrm{Cd}$ are $0.30,0.50$, and $0.05 \mathrm{mg} / \mathrm{kg}$ wet wt., respectively. The amounts of these toxic metals in muscle tissues of the common carp are not risky to people health. The data of the present study show a useful baseline to determine any future changes in local pollution of the Kizılırmak

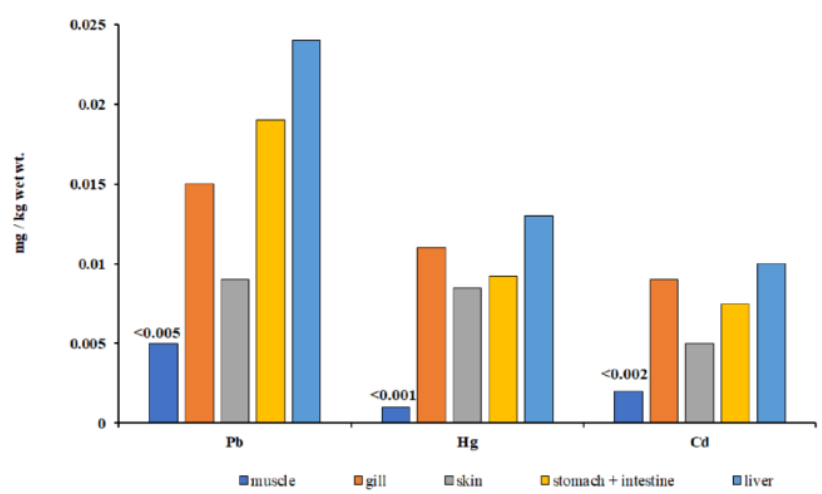

Figure 1. Concentrations of non-essential metals in the common carp from Kizilırmak.

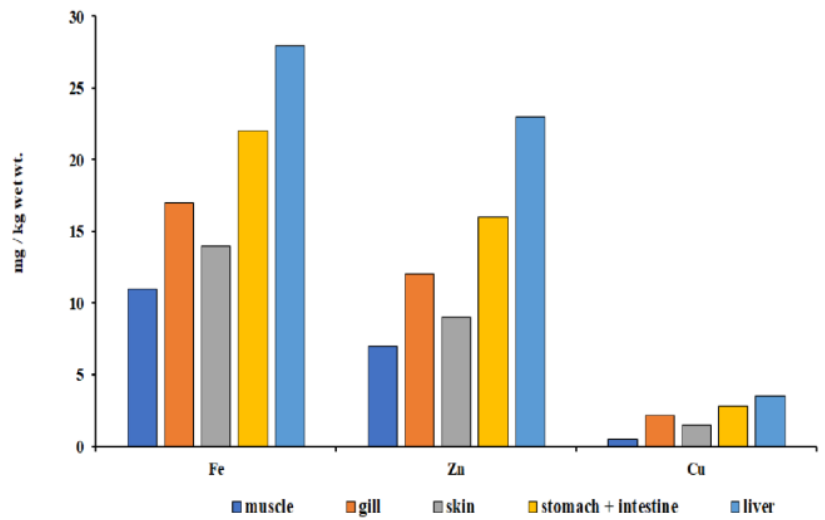

Figure 2. Concentrations of essential metals in the common carp from Kizilırmak.

However, these toxic metals in other tissues were detected. $\mathrm{Pb}$ is a potentially toxic metal, especially in the aquatic environment. Seafood is generally accepted as the main source of mercury, a highly toxic metal, in food chain. $\mathrm{Cd}$ is a highly toxic metal for fish and tends to be accumulated in biota very quickly. For this, the fish must be cleaned very well before consumption. Organs or other tissues outside the muscle tissues should be separated, including the skin, and then cooking should be started. Therefore, the consumption of the common carp, studied in this research, does not constitute a risk to public health. Similarly, consumption of C. carpio from Karasu Stream has also been found to pose no danger (Bat et al., 2019).
Among studied metals, Fe had highest mean concentration in all tissues followed $\mathrm{Zn}$ and $\mathrm{Cu}$ (Figure 2). $\mathrm{Fe}$ is the most abundant metallic element. In the present study, the highest mean Fe concentration was determined in all tissues of $C$. carpio. $\mathrm{Zn}$ is essential metal but, being exposed to very high levels may toxic effects. The highest mean $\mathrm{Zn}$ amount in the edible tissues was $7 \mathrm{mg} / \mathrm{kg}$ wet wt. $\mathrm{Cu}$ is also an essential metal existing at small levels in a variety of cells and tissues and at high levels in the liver. However, it is toxic if taken at high levels. In this study, the highest mean $\mathrm{Cu}$ concentration of the common carp was detected as $1.5 \mathrm{mg} / \mathrm{kg}$ wet wt. in skin $2.2 \mathrm{mg} / \mathrm{kg}$ wet wt., in gills, $2.8 \mathrm{mg} / \mathrm{kg}$ wet wt. in stomach + intestine and $3.5 \mathrm{mg} / \mathrm{kg}$ wet wt. liver. The lowest levels of $\mathrm{Cu}$ was found in edible tissues $(0.51 \mathrm{mg} / \mathrm{kg}$ wet wt.). As it can be seen, there is not any risk to public health in consumption of carp in terms of $\mathrm{Fe}, \mathrm{Zn}$ and $\mathrm{Cu}$.

The concentrations of $\mathrm{Fe}, \mathrm{Zn}, \mathrm{Cu}$ and $\mathrm{Pb}$ in $C$. carpio were liver $>$ stomach + intestine $>$ gill $>$ skin $>$ muscle, while the $\mathrm{Hg}$ and $\mathrm{Cd}$ levels were liver $>$ gill $>$ stomach + intestine $>$ skin $>$ muscle, respectively. Highest mean concentrations of metals were observed in liver tissues. According to the data, with regard to liver, the maximum levels of $\mathrm{Fe}, \mathrm{Zn}, \mathrm{Cu}, \mathrm{Pb}, \mathrm{Hg}$ and $\mathrm{Cd}$ were 28, 23, $3.5,0.024,0.013$ and $0.01 \mathrm{mg} / \mathrm{kg}$ wet wt., respectively. The result of the study showed that the liver tissue tends to accumulate both toxic and non-toxic metals more than other studied tissues and organ. It may be explained with the physiological metabolism of the fish. Metal accumulation in fish tissues and organs depend on the physiological and metabolic activities of them. They tend to interact with metallothionein protein. The mentioned protein exists in high level in liver tissue because liver is the main organ that provides metallothionein. This agrees with previous studies from Altınkaya Dam Lake of Samsun (Öztürk et al., 1995; Bat and Öztekin, 2018), Lake Balık of Kizılırmak Delta (Bat et al., 2015), Karakaya Dam Lake (Küçükbay and Örün, 2003). The higher concentrations in liver represent storage capability of metals, it is known that liver has been considered to be the inner organs for metals accumulation in fish. The higher amounts of metals in liver relative to other tissues was attributed to the affinity of metallothionein protein. Similar results were also observed for $\mathrm{Cu}$ and $\mathrm{Fe}$ in Tinca tinca collected from Siddiklı Küçükboğaz Dam Lake (Yilmaz et al., 2016).

Fish uptake metals from water through their gills and skins or through contaminated food. Gills are the first barrier and main entrance of dissolved metals and responsible for homeostasis of essential metals such as $\mathrm{Fe}$ and $\mathrm{Cu}$ in hepatic metallothionein biological with detoxification of metal ions. One of the major routes of metal assimilation in fish are water via the gills (Dallinger et al., 1987). The uptake of metals in the gills could be due 
to the fact that gills serve as the respiratory organ which metal ions are absorbed. The levels of metals in gills also reflects their levels in water where fish habitat.

The common carp prefers shallow waters with dense macrophyte cover and slower-current bodies of water with muddy sediments, however these fish are tolerant in a wide variety of aquatic habitats (Bat et al., 2008). The metals tended to settle to the bottom and accumulate in sediment year after year (Bat and Özkan, 2019). As a result, they have the potential to accumulate metals. These non-biodegradable and non-essential metals such as $\mathrm{Cd}, \mathrm{Hg}$ and $\mathrm{Pb}$ are highly toxic contaminants and their uptake and bioaccumulation in fish may cause serious problem directly on food chain and eventually to people (Bat, 2017).

\section{CONCLUSION}

Overall $\mathrm{Fe}$ and $\mathrm{Zn}$ were detected in higher concentrations followed by $\mathrm{Cu}$. Non-essential metals $\mathrm{Pb}$, $\mathrm{Hg}$ and $\mathrm{Cd}$ could only be detected mainly in liver and other tissues and organs except muscle tissues. Metal concentrations in Kizılırmak is due to discharge of sewage and urban effluents in this area (Altas and Büyükgüngör, 2006). This indicates that fish of natural river waters is contaminated with metals.

The levels of essential metals were always higher in organs and tissues of the fish individuals than the nonessential metals and there appeared to be some rapport with the metals to particular organs and tissues of the common carp and finally the muscle tissues had the minimum levels of these metals.

\section{CONFLICT OF INTEREST STATEMENT}

The authors declare that there are no conflicts of interest.

\section{REFERENCES}

Akbulut, M., Bat, L., Çulha, M. \& Satılmış, H.H. (2000). Kızılırmak Deltasının sorunları ve çözüm yolları. Su Ürünleri Seтроzуити, 20-22 Eylül 2000, Sinop, 655-661.

Altaş, L. \& Büyükgüngör, H. (2007). Heavy metal pollution in the Black Sea shore and offshore of Turkey. Environmental Geology, 52(3), 469-476.

Bakan, G., Özkoç, H. B., Tülek, S. \& Cüce, H. (2010). Integrated environmental quality assessment of Kizllırmak River and its coastal environment. Turkish Journal of Fisheries and Aquatic Sciences, 10(4), 453-462.

Bat, L., Erdem, Y., Ustaoğlu-Tırıl, S., \& Yardım, Ö. (2008). Balık Sistematiği. XVIII+ 270 s. Nobel Yayın Dağıtım Ltd. Şti., Ankara.
Bat, L., Arıcı, E., Sezgin, M. \& Şahin, F. (2015). Heavy metal levels in the liver and muscle tissues of the four commercial fishes from Lake Balik, Kizilırmak Delta (Samsun, Turkey). Journal of Coastal Life Medicine, 3(12), 950-955.

Bat, L. (2017). The contamination status of heavy metals in fish from the Black Sea, Turkey and potential risks to human health. In: Sezgin, M., Bat, L., Ürkmez, D., Arıcı, E., Öztürk, B. (Eds.) Black Sea Marine Environment: The Turkish Shelf. Turkish Marine Research Foundation (TUDAV), Publication, 46, 322-418.

Bat, L. \& Öztekin, A. (2018). Heavy metal levels in muscle, livers and digestive tracts of Cyprinus carpio L., 1758 from Altınkaya Dam Lake of Samsun Province, Turkey. 185-189 p., In: MARFRESH2018 (First International Marine \& Freshwater Sciences Symposium), 18-21 October 2018 Kemer, Antalya, Turkey.

Bat, L. \& Özkan, E. Y. (2019). Heavy metal levels in sediment of the Turkish Black Sea coast. In Oceanography and Coastal Informatics: Breakthroughs in Research and Practice (pp. 86107). IGI Global, USA.

Bat, L., Şahin, F., Öztekin, A., Arici, E. \& Yardim, Ö. (2019). Assessment of $\mathrm{Cd}, \mathrm{Hg}, \mathrm{Pb}, \mathrm{Cu}$ and $\mathrm{Zn}$ amounts in muscles of Cyprinus carpio from Karasu Stream, Sinop. Current Agriculture Research Journal, 7(2), 171-180.

Bernhard, M. (1976). Manual of methods in aquatic environment research. Part 3-Sampling and analyses of biological material (guidelines for the FAO (GFCM)/UNEP Joint Coordinated Project on Pollution in the Mediterranean). Documents Techniques FAO sur les Pèches (FAO).

Dallinger, R., Prosi, F., Segner, H. \& Back, H. (1987). Contaminated food and uptake of heavy metals by fish: a review and a proposal for further research. Oecologia, 73(1), 91-98.

Demirkalp, F.Y. (1992a). Bafra Balık Gölleri (BalıkgölüUzungöl)'nde yaşayan sazan balığı (Cyprinus carpio L., 1758)'nın büyüme özellikleri. Doğa Türk Zooloji Dergisi, 16, 161-175.

Demirkalp, F.Y. (1992b). Bafra Balık Gölleri (BalıkgölüUzungöl)'nde yaşayan Cyprinus carpio Linnaeus, 1758, Mugil cephalus Linnaeus, 1758 ve Stizostedion lucioperca (Linnaeus, 1758)'nın üreme biyolojileri. Turkish Journal of Zoology, 16(4), 311-322.

European Commission. (2006). Commission Regulation (EC) No 1881/2006 of 19 December 2006 setting maximum levels for certain contaminants in foodstuffs. Off J Eur Union, 364 (365-324).

Küçükbay, F.Z. \& Örün, İ. (2003). Copper and zinc accumulation in tissues of the freshwater fish Cyprinus carpio L. 1758 collected from the Karakaya Dam Lake, Malatya (Turkey). Fresenius Environmental Bulletin, 12, 62-66.

Özesmi, U. (2006). Ecosystems in the mind: Fuzzy cognitive maps of the Kizilirmak Delta Wetlands in Turkey. arXiv preprint q-bio/0603022. 
Öztürk, M., Bat, L. \& Öztürk, M. (1995). Altınkaya Barajı'nda (Samsun) yaşayan Cyprinus carpio L., 1758 türünün çeşitli organ ve dokularındaki bazı ağır metallerin birikimi. 650-667p. II. Ulusal Ekoloji ve Çevre Kongresi Bildirileri, 11-13 Eylül, Ankara.

Samsunlu, A., Akca, L., Kinaci, C., Findik, N. \& Tanik, A. (2002). Significance of wetlands in water quality management-past and present situation of Kizilirmak Delta, Turkey. Water science and technology, 46(8), 145-152.

Schelle, P., Collier, U. \& Pittock, J. (2004). Rivers at risk: dams and the future of freshwater ecosystems. In: World wildlife fund (WWF). Paper to the 7th international river symposium, Sept (Vol. 4).

Yılmaz, S. \& Polat, N. (2008). Cyprinus carpio L., 1758 (Sazan)'nun yaş tayini için farklı kemiksi yapıların değerlendirilmesi. SDÜ Fen Edebiyat Fakültesi, Fen Dergisi yayınları, 3(2), 149-161.

Yilmaz, S., Yazicioğlu, O. \& Polat, N. (2012). Bafra Balık Gölleri (Samsun, Türkiye)'ndeki sazan (Cyprinus carpio L., 1758)'ın yaş ve büyüme özellikleri. Karadeniz Fen Bilimleri Dergisi, 3(2), $1-12$.

Yilmaz, M., Teber, C., Akkan, T., Er, C., Kariptas, E. \& Ciftci, H. (2016). Determination of heavy metal levels in different tissues of tench (Tinca tinca 1., 1758) from Siddikli Kucukbogaz dam lake (Kirsehir), Turkey. Fresenius Environmental Bulletin, 25(6), 1972-1977.

Zar, J.H. (1984). Biostatistical analysis. Second edition. Prentice Hall, Int., New Jersey. 